\title{
Relative authorities: constitutional reasonable resistances against Inter-American Court's doctrines
}

Autoridades relativas: resistencias constitucionales razonables contra

las doctrinas de la Corte Interamericana

\author{
Yota Negishi ${ }^{1}$ \\ Seinan Gakuin University
}

\begin{abstract}
Summary
This article illustrates the constitutional reasoning upon which domestic courts exhibit resistance to relativize Inter-American Court's doctrines. The San José Court has given constitutional reasoning in a dual dimension, the doctrine of corpus juris internacional, and the doctrine of control de convencionalidad. Constitutional reasonable resistance against such Inter-American authoritative doctrines has become manifest in recent cases concerning amnesty in transitional justice, conflicting rights between private parties, and the invalidation of domestic decisions. To overcome mutual backlashes between Inter-American and domestic judges, this paper seeks their potential of a more harmonious, democracy-oriented interaction on the basis of shared constitutional reasoning.
\end{abstract}

\section{Keywords}

Inter-American Court of Human Rights / International corpus juris / Conventionality control / Constitutional reasoning / Reasonable resistance / Relative authority of law.

\section{Resumen}

Este artículo ilustra el razonamiento constitucional sobre el cual los tribunales nacionales muestran resistencia a relativizar las doctrinas de la Corte Interamericana. La Corte de San José ha dado un razonamiento constitucional en una doble dimensión, la doctrina del corpus juris internacional, y la doctrina del control de convencionalidad. La resistencia constitucional razonable contra tales doctrinas autorizadas interamericanas se ha manifestado en casos recientes relativos a la amnistía en la justicia transicional, los derechos conflictivos entre partes privadas y la invalidación de las decisiones internas. Para superar las reacciones recíprocas mutuas entre jueces interamericanos y nacionales, este artículo busca su potencial de una interacción más armoniosa y orientada a la democracia sobre la base del razonamiento constitucional compartido.

\section{Palabras clave}

Corte Interamericana de Derechos Humanos / Corpus juris internacional / Control de convencionalidad / Doctrina constitucional / Resistencia razonable / Autoridad relativa de ley.

\section{Introduction}

In Latin America, the Inter-American Court of Human Rights (IACtHR) and domestic courts of States Parties to the American Convention on Human Rights (ACHR) have collaborated to transform constitutional cultures towards the future emergence of Ius Constitutionale Commune (Von Bogdandy et al., 2017). In this context, we may observe the co-existence 
of international and national authorities, both of which rely on the constitutional modes of "judicial" argumentation for regulating their interaction (Jakab, Dyevre and Itzcovich, 2017). Despite its international character, the IACtHR has recently behaved as a constitutional court in order to cultivate constitutional argumentative practices of domestic courts (BurgorgueLarsen, 2014; mutatis mutandis for the European Court of Human Rights, Gerards, 2017). The interaction between different constitutional reason-giving institutions within the InterAmerican framework of human rights protection has abundant lessons for reconsidering the traditional problem of relative authorities (Potter, 1925).

Among the variety of constitutional reasoning, this contribution focuses on the constitutional reasonable resistance by Latin American domestic courts against the San José Court. It is now increasingly found that domestic courts around the world tend to give reasons for resisting against international legal norms incompatible with national fundamental principles (Palombino, 2015). The same tendency emerges in Latin America as the IACtHR exercises authority corresponding to a regional constitutional court.

Against this background, this article illustrates the constitutional reasoning upon which domestic courts exhibit resistance to relativize Inter-American Court's doctrines. After this Introduction (1), the following section describes IACtHR's authoritative doctrines reflecting its role as a constitutional court in Latin America (2). Next this article in turn examines the practices of constitutional judges who make counter-arguments against these Inter-American doctrines (3). To integrate these both practices, the paper then sophisticates a Latin American version of relativist theory of authority of international and national law (4). Finally, some messages are conveyed to both Inter-American and constitutional judges as concluding remarks (5).

\section{Inter-American Court's doctrines}

As a preliminary step, this section confirms the authoritative doctrines developed in the IACtHR jurisprudence. Indeed, the San José Court has given constitutional reasoning in a dual dimension: the doctrine of "corpus juris internacional" bridging regional and universal human rights standards (2.1); and the doctrine of "control de convencionalidad" integrating international and domestic human rights sources (2.2).

\subsection{The doctrine of "corpus juris internacional"}

In its interpretive practice, the Inter-American Court starts with the general (Article 31 of the Vienna Convention on the Law of Treaties) and regional (Article 29 of the ACHR) rules of interpretation. In most cases, the priority is put on objectivism over voluntarism to enable evolutive interpretation on the assumption that "human rights treaties are living instruments whose interpretation must consider the changes over time and present-day conditions" (The Right to Information on Consular Assistance, para. 114). For this dynamic purpose, the Regional Court, as if behaving as the Universal Court, situates the regional Convention within the allegedly existing corpus juris of international human rights law (Tigroudja, 2010, pp. 473474). El corpus juris internacional is, according to the San José Court, composed of both formal and material sources including decisions and opinions of international courts, views and recommendations of treaty bodies, declarations and guidelines of international organizations and expert groups etc. (I.V. vs. Bolivia, para. 168).

In interpreting the regional instrument, Inter-American judges have reluctantly avoided to rely on regional consensus among States Parties. This is because "[s]etting international standards by reference to actual national practice would risk the adoption of very low targets" (Neuman, 2008, p. 107). To quote its wording: "the fact that this is a controversial issue in 
some sectors and countries, and that it is not necessarily a matter of consensus, cannot lead this Court to abstain from issuing a decision, since in doing so it must refer solely and exclusively to the stipulations of the international obligations arising from a sovereign decision by the States to adhere to the American Convention" (Atala Riffo, para. 92). In adopting evolutionary interpretation, the San José Court thus causes the "sensible erosion of the principle of sovereign equality" by shifting the centrality from individual State consent to universally accumulated practices (Pascual Vives, 2014, pp. 133-134).

Consequently, in expanding regional criteria in light of universal materials, the IACtHR attaches more weight to universal consensus than regional consensus. In line with the concept of corpus juris internacional, the San José Court emphasizes opinio juris communis, namely, "the expression of the universal juridical conscience through the observance, by most of the members of the international community, of a determined practice because it is obligatory" (Baena-Ricardo, para. 102). Judge Antônio Augusto Cançado Trindade explains that universal juridical conscience may be practically observed "in the elaboration of adopted texts of international treaties, in the proceedings before international tribunals and in international case-law, and in the works of international legal doctrine" (cf. 2010, p. 139; see also Negishi, 2017b). To justify its evolutionary interpretive practice beyond the regional framework, "the IACtHR seems to imply that it draws legitimacy not from the States Parties, but from external stakeholders, and an abstract idea of human rights and human dignity" (Lixinski, 2017, p. 94).

\subsection{The doctrine of "control de convencionalidad"}

The San José Court is getting much more like a constitutional court by inviting itself into the member States' legal systems in order to force them to conform to Convention standards (Hennebel, 2011, pp. 71-76). Such a constitutional role becomes evident especially when the IACtHR launched the concept of control de convencionalidad: "When a State has ratified an international treaty such as the American Convention, the judges are also subject to it; this obliges them to ensure that the effet util of the Convention is not reduced or annulled by the application of laws contrary to its provisions, object and purpose. In other words, the organs of the Judiciary should exercise not only a control of constitutionality, but also of 'conventionality' ex officio between domestic norms and the American Convention; evidently in the context of their respective spheres of competence and the corresponding procedural regulations" (The Dismissed Congressional Employees v. Peru, para. 128; see also Negishi 2017a, 2017c).

The San José Court's attitude seems problematic because the principle of subsidiarity literally means the negative function to limit the intervention of international instance. The conventionality control doctrine rather appears to restricting national margin of appreciation in that "the judiciary must implement a narrow conventionality control, where the only discretion it has is to ascertain which cases fall in the same category as the one considered by the IACtHR" (Ruiz-Chiriboga, 2010, p. 205). In particular, "considerations of subsidiarity play a fairly small role in the IACtHR's remedial practice" since the Court "feels free to select remedies over the objection of the respondent state" (Neuman, 2013, pp. 363-365 and 371-374).

This does not mean, however, that the principle of subsidiarity negates the conventionality control doctrine; rather such a "dynamic and complementary control" has been established between domestic authorities who have the primary obligation and the international subsidiary instance (The Santo Domingo Massacre v. Colombia, para. 143). In fact, the positive dimension of subsidiarity (Dulitzky, 2015) functions to centralize the competence toward human rights courts to discover underlying structural problems, indicate particular measures for rectifying those problems, and, if necessary, pierce the veil of "the state" to designate the liable state organs: 
Figuratively speaking, doctors are no longer limited to examining patients' conditions just by touching their skin and telling them their disease's name. When patients fail to recover by themselves, medical experts then identify the affected areas almost exactly, prescribe drugs to completely eliminate their sources, and, if the situation demands it, section their bodies to directly encourage individual body organs pertaining to the identified causes (Negishi, 2016, p. 149).

\section{Constitutional reasonable resistances}

This section examines the cases where national authorities engaged in the argumentative opposition against IACtHR's decisions on the basis of constitutional reasoning. Such constitutional reasonable resistance has become manifest in recent cases concerning amnesty in transitional justice (3.1), conflicting rights between private parties (3.2), and the invalidation of domestic decisions (3.3).

\subsection{Amnesty in peace process: Gelman v. Uruguay}

The first example Gelman is the enforced disappearance case in Uruguay within the scheme of la Operación Cóndor. In transiting from the military regime to a constitutional democratic system, the Uruguayan Parliament in 1986 promulgated the Expiry Law to grant amnesty to those responsible for such crimes. La Ley de Caducidad was publicly supported through the exercises of direct democracy in 1989 and 2009.

Against this background, the IACtHR rendered judgment on merits on 24 February 2011. The Gelman ruling was slightly different from precedents regarding self-amnesty in that the Expiry Law in question allegedly gained democratic legitimacy. For the San José Court, the primary mission was to defend its individual-oriented case-law from the risk of the majoritarian rule:

The fact that the Expiry Law of the State has been approved in a democratic regime and yet ratified or supported by the public, on two occasions, namely, through the exercise of direct democracy, does not automatically or by itself grant legitimacy under International Law. [...] The democratic legitimacy of specific facts in a society is limited by the norms of protection of human rights recognized in international treaties, [...] in such a form that the existence of one true democratic regime is determined by both its formal and substantial characteristics, and therefore, particularly in cases of serious violations of non-revocable norms of International Law, the protection of human rights constitutes an impassable [infranqueable] limit to the rule of majority (paras. 238-239).

The Supreme Court of Justice of Uruguay clearly showed a sense of rebellion against the InterAmerican top-down decision. In the 2009 Sabalsagaray judgment, la Corte Suprema de Justicia once disregarded the Expiry Law as unconstitutional, which la Corte Interamericana highly evaluated as "adecuado control de convencionalidad" (Gelman, 2011, para. 239). Nevertheless, the judgment on 22 February 2013 declared the unconstitutionality of Articles 2 and 3 of Law No. 18831 enacted for implementing the IACtHR judgment for violating the constitutional principle of non-retroactivity. To justify their own constitutional logic, the Uruguayan highest judges emphasized that,

[...] while it is beyond any discussion that the IACtHR is the final interpreter of the ACHR — naturally within the sphere of its jurisdiction — it cannot be denied 
that the final interpreter of the Constitution of the Oriental Republic of Uruguay is the Supreme Court of Justice (Supreme Court of Justice of Uruguay, 2013, Considerando III.a.).

Shortly after receiving the harsh backlash from Montevideo, the San José Court in turn issued an order on compliance with the judgment on 20 March 2013. To counter the Supreme Court's argument distinguishing Inter-American and constitutional authorities, the bindingness of IACtHR judgments was resolutely reiterated:

According to International Law which the State has accepted in a democratic and sovereign manner, it is unacceptable that once the Inter-American Court has issued a judgment with the authority of res judicata, the domestic law or its authorities should seek to leave it without effects (Supreme Court, 2013, para. 90).

\subsection{Conflict of rights: Artavia Murillo and others v. Costa Rica}

We move to the second example Artavia Murillo pertaining to the alleged human rights violations resulting from the presumed general prohibition of the practice of in vitro fertilization (IVF). Although IVF techniques were authorized by the 1995 Executive Decree 24029-S, it was declared unconstitutional by the Constitutional Chamber of the Supreme Court of Justice in Judgment No. 2000-02306 of 15 March 2000. The Chamber's decision allegedly constituted the arbitrary interference in the right to private life and family in the name of the absolute protection of the right to life.

Facing such a difficult balancing task, the IACtHR in the judgment on merits on 28 November 2012 relativized the absolute protection of one of those conflicting rights supported by the supremacy of the national constitution. Thereby, it created an open circumstance for striking a proportionate balance most favorable to persons in terms of their substance (para. 259; see also Negishi, 2017a, pp. 478-479). The San José Court stepped further to find "it appropriate to indicate the way in which the sacrifice of the rights involved in this case was excessive in comparison to the benefits referred to with the protection of the embryo," in spite of recognizing that "it [was] not necessary to make a detailed analysis of each of these requirements, or to assess the disputes regarding the declaration of unconstitutionality in the formal sense based on the presumed violation of the principle of legal reserve" (para. 273). It was then concluded that the Chamber disproportionately interfered with private and family life.

The Costa Rican constitutional judges were again in favor of the right to life in opposition to Inter-American judges. To implement the reparation measure indicated by the IACtHR, the Executive afresh issued the Decree 39210-MP-S to authorize IVF techniques. It was however declared unconstitutional by the Constitutional Chamber judgment on 3 February 2016 for violating constitutional principles of reserva de ley and democracy. More concretely, the following constitutional reason was given:

Compliance with the judgment of the IACHR [...] implies a reconfiguration of the level and scope of the right to life, as well as the definition of a new embryo protection status, in order to perform a new weighting of the protection of the other rights involved, [...], which, by virtue of the principle of reserva de ley, which governs in the matter of fundamental rights, can only be done by means of a formal law promulgated by the Legislative Assembly (Considerando IV). 
So far this case also represents the confrontation between constitutional and Inter-American judges. In the order on compliance on 26 February 2016, the IACtHR valued positively the efforts made by the Executive to annul the IVF prohibition (para. 17), while it considered the negative attitude of the Constitutional Chamber just two weeks before as an obstacle for implementing the judgment (paras. 18-19). As a remarkable position taken in this context, the Dissenting Opinion of Judge Vio Grossi clearly mentions "el margen de apreciación del Estado" recognized for implementing the obligations under international law (para. 25).

\subsection{Revocation of domestic judgment: Fontevecchia and D'Amico v. Argentina}

The third example for the present purpose is Fontevecchia and D'Amico relating to the civil sentence of the Supreme Court of Argentina imposing compensation on journalists who published articles on political scandals. The main cause of the conflict between national and international judges here is the possibility of revoking the Supreme Court's decision. In the judgment on merits on 29 November 2011, having determined the violation of the victims' freedom of expression, the IACtHR ordered as a reparation measure that "the State must revoke [in the authentic Español text 'dejar sin efecto'] the decision” (para. 105).

This sensitive reparation order provoked the critical reaction of the Supreme Court in the judgment on 14 February 2017. According to the Argentine Supreme Court, the dejar sin efecto order implies the substitution of its authority by the Inter-American Court, which is clear transgression of constitutional principles. This position is reinforced with the sovereignty-driven constitutional reasoning: "The constituent has enshrined in Article 27 a sphere of sovereign reserve, delimited by the principles of public law established in the National Constitution, to which international treaties must be adjusted and with which must keep compliance" (Considerando 16). In the Opinion of Judge Horacio Rosatti, the term "esfera de reserva soberana" is notably rephrased as "margen de apreciación" (para. 5).

The question casted from Buenos Aires was answered in San José negatively with the order on compliance on 18 October 2017. Frist of all, the Inter-American Court clarified that the meaning of its own wording dejar sin efecto is not synonymous with revoking as interpreted by the Argentine Supreme Court but is rather that "the State should adopt 'the judicial, administrative and other measures that may be necessary' to 'render ineffective' such sentences" (para. 16). Next, the IACtHR mentioned the existence of other type of legal act, different from such revocation, to comply with the ordered reparation measure other means for that purpose (paras. 20-21).

\section{The relativity of Inter-American and constitutional authorities}

To overcome mutual backlashes between Inter-American and domestic judges examined above, this section finally seeks their potential of a more harmonious interaction on the basis of shared constitutional reasoning. It starts with reviewing the literature establishing the relativist theories on multiple legal authorities (4.1). In contrast with the previous section dealing with frustrated monologue cases, this part gives considerable attention to a successful dialogue where constitutional reasoning well bridged Inter-American and domestic values (4.2). We may therefrom extract important lessons to a healthier pluralist environment in an emerging constitutional order in Latin America (4.3).

\subsection{Relativist theories on authority of law}

International law has traditionally derived its legitimacy simply from the consent of sovereign State (Lister, 2010; Werner, 2016). Such a voluntarist approach, however, encounters a natural 
objection that the consent of some states does not reflect the interests of most people in those states. Thus, another alternative is currently being pursued, for example, under the "democratic state consent" model (Christiano, 2010). The democracy-oriented model is particularly convincing when the authority of international law is situated in the relative relationship with the authority of constitutional law that can draw legitimacy directly from the will of the people.

As a prominent theoretical approach, Samantha Besson proposes the co-ordination based theory of legal authority. She puts the justification of legitimate authority mostly in the "co-ordinating ability" of international law in circumstances of "reasonable disagreement" (2009, pp. 352-355). Besson argues that the role of state consent is best understood and justified by reference to the circumstances of reasonable disagreement about and in international law, and hence to state democracy and equality (2016, pp. 300-302). In such reasonable disagreement cases, "democratic state consent should work as an exception to the prima facie legitimate authority of international law" (2016, p. 307).

Nicole Roughan $(2013,2016)$ similarly theorizes the conjunctive justification of authority of law. Her legal-philosophical framework presupposes that authorities have the standing of authority conferred upon them through some valuable process including democratic values and that the authorities better enable subjects to comply with the reasons that apply to them (2016, p. 343). Roughan suggests that "[r]elative authorities might, depending on context, need to cooperate, coordinate or tolerate one another if they are to have legitimacy," and therefore, "even relationships of conflict are justified" (2016, p. 348).

From a practical viewpoint, Başak Çalı also advocates a "reflexive authority" of international law before domestic courts. To overcome the limits of traditional monism and dualism debate, her reflexive approach categorizes more minutely the scope and extent (strong, weak or rebuttable) of authority claim of international law. Domestic judges are under the duty to disregard the domestic law manifestly incompatible with a strict international legal obligation. Meanwhile, they are given a certain extent of discretion to implement when confronted with a weak obligation of international law, or even may set aside a rebuttable international legal mandate (2015, pp. 146-157).

These relativist theories of legal authorities can be corroborated with the Jurisdictional Immunities of the State (Germany v. Italy) scenario. In this instance, the Italian Constitutional Court with its Sentenza 238/2014 resisted against the judgment of the International Court of Justice (ICJ) that prioritized state immunity over individual victims. The Judgment 238/2014 is based on the constitutional reason that the constitutional right to judicial protection (Articles 2 and 24) is not only "one of the supreme principles of our [Italian] constitutional order, intrinsically connected to the principle of democracy itself" but also "one of the greatest principles of legal culture in democratic systems of our times". It should be carefully read that the Constitutional Court indeed took international law into consideration in the process of balancing the different constitutional principles at stake. (Considerato in diritto para. 3.4; see Iovane, 2016, pp. 600-602). In this process, the Italian Constitutional Court felt entitled to perform vis-à-vis the international and the United Nations legal orders including the ICJ, by indicating a path that those orders should follow if they want to embrace a meaningful process of "democratization" (2015, p. 404).

\subsection{The Massacre of El Mozote and the surrounding areas v. El Salvador}

In the context of Latin America, the El Mozote case beautifully illustrates the relativist theories on international and national authorities in light of constitutional reasoning. This case concerned the alleged massacres occurred during the ruthless period of the so-called "counterinsurgency" 
operations, deployed against civilians on a massive scale by the Salvadoran army during the armed conflict. Although the 1992 the Chapultepec Peace Accord ending hostilities clearly mentions "the need to clarify and put an end to any indication of impunity," the Legislative Assembly of the Republic of El Salvador enacted the 1993 Law of General Amnesty for the Consolidation of Peace to extended the benefit of unrestricted amnesty under the 1992 National Reconciliation Law.

In the merits on 25 October 2012, the IACtHR resolutely maintained its jurisprudence on amnesty laws. Despite the apparently democratic process through which the Law of General Amnesty was adopted, it was regarded as evidently incompatible with the ACHR and lacking legal effects. We should not overlook in this context the concurring opinion of Judge Diego García Sayán, adhered by Judges Leonardo A. Franco, Margarette May Macaulay, Rhadys Abreu Blondet and Alberto Pérez Pérez. Their opinion complemented the majority position in terms of the special conditions of transitional justice as follows:

In these [transitional situations between armed conflicts and peace], taking into consideration that none of those rights and obligations is of an absolute character, it is legitimate that they be weighed in such a way that the satisfaction of some does not affect the exercise of the others disproportionately. Thus, the degree of justice that can be achieved is not an isolated component from which legitimate frustrations and dissatisfactions can arise, but part of an ambitious process of transition towards mutual tolerance and peace (para. 38).

In line with this thoughtful Opinion, the Constitutional Chamber the Supreme Court of El Salvador in the Judgment on 13 July 2016 tactfully orchestrated its constitutional reasoning in favor of both international and national mandates. As a starting point for dialogue, the constitutional guardian evaluated the Inter-American authority in that the latter "without disregarding the sovereign right that States retain to decree amnesties in situations of post-armed conflict, has ruled on the incompatibility of certain amnesty laws — specifically self-amnestieswith international law and with the international obligations of states" (Considerando IV.6.A.). By friendly re-appraising, and at the same time, re-characterizing the Inter-American jurisprudence as developed mainly in "self-"amnesty cases, the Constitutional Chamber skillfully arranged its own field to create the jurisprudence on "post-armed conflict" amnesty in terms of constitutional reasoning. The Chamber's position was corroborated with a constitutional comparative analysis of transitional cases including Argentina and Colombia (Considerando V.1.A.) To differentiate from the Inter-American Court that links strict international obligations with "all" violation of protected rights, the Salvadorian Court identified the actually relevant criteria to be applied only in "serious" violations of human rights (Considerando V.2.A.). Within the reformulated framework, the proportionality was even more minutely evaluated between "the need to ensure certain legitimate public interests - such as peace, political stability and national reconciliation - and the state's inalienable obligation to investigate and sanction violations of fundamental rights." (Considerando V.2.B.)

Although the IACtHR and the Constitutional Chamber proceeded in different paths, they eventually joined together in the conclusion that Ley de Amnistia General para la Consolidación de la Paz was subject to control of constitutionality and conventionality. As a subsequent progress, the Second Court of First Instance of San Francisco Goterahad subsequently ordered the closure of the proceedings in application of the Act, required the proceedings to be reopened. As a closing remark of the dialogue, the IACtHR issued the order 
on 31 August 2017 to declare that El Salvador have given full compliance with the judgment.

\subsection{Relativizing Inter-American Court's doctrines through constitutional reasoning}

This Salvadorian approach in El Mozote elaborated a thought-provoking constitutional reasoning that respectfully aims to relativize IACtHR's absolutist doctrines. On this point, Carlos Arturo Villagrán Sandoval and Fabia Fernandes Carvalho Veçoso have already made an insightful comment that the most interesting aspect of the Salvadorian decision was that it presented the Chamber as a catalyst in the bottom-up construction of democratic values in a dialectic manner. (2016, pp. 1636-1637, emphasis added). We may observe the dual aspect of such a bottom-up democratization

First, the Constitutional Chamber constructively criticized the IACtHR's comparative method for ascertaining the international corpus juris. As we confirmed above, the InterAmerican comparative approach has been the target of criticism for "undertak[ing] a fairly superficial reading of the law of the other countries involved, particularly in the absence of IACtHR cases dealing with the same set of laws in the other jurisdictions" (Lixinski, 2017, p. 79). The Constitutional Chamber, in order to overcome such a flaw stemming from the top-down approach of the Inter-American Court, intended to build a bottom-up democratic consensus among States Parties by comparing constitutional peers' practices in this region.

Second, the Constitutional Chamber attenuated the IACtHR's ultimate authority in exercising the control of conventionality. In the Artavia Murillo judgment on merits mentioned before, the IACtHR boldly took a constitutional role of assessing an appropriate balance to mitigate the excessive sacrifice of the rights involved for the benefits referred to with the protection of the embryo, though acknowledging the non-necessity of such a detailed analysis by itself. On the contrary, the Constitutional Chamber claimed its "better placed" position than the Inter-American Court's top-down standpoint to assess constitutional proportionality to reflect democratic values in the sensitive context of transitional justice.

As is implied in the Salvadorian case, such a double bottom-up construction of democratic consensus though reasonable constitutional reasoning contributes to reinforcing, rather than demolishing, the legitimate authority of international law. To facilitate the possibility, the IACtHR is expected to systematize a more deferential approach to States Parties in this particular case (Contesse, 2016, p. 137). In particular, the relevance of national margin of appreciation should be sincerely tackled, which is especially apt in sensitive contexts such as transitional justice, where the very different historical, political, and social circumstances demand unique solutions (Acosta López, 2016, p. 181; see also Negishi, 2016, pp. 149-151).

\section{Conclusions}

This paper has demonstrated that the constitutional reasoning upon which domestic courts exhibit resistance has the potential to relativize Inter-American Court's doctrines. The San José Court has given constitutional reasoning in a dual dimension, the doctrine of corpus juris internacional, and the doctrine of control de convencionalidad. Such Inter-American authoritative doctrines have been recently challenged by domestic courts based on constitutional modes of argumentation. It would not be desirable for human rights protection that both international and domestic authorities launch monologue by retreating to the safe havens constructed with their own logic. In order to create a more open, healthier environment for dialogue, constitutional reasoning should be shared among Inter-American and domestic judges even through tolerable resistance. This paper therefore concludes that constitutional reasonable resistance against is permissible so long as it contributes to a more harmonious, democracy-oriented interaction on 
the basis of shared constitutional reasoning.

It is true that, since its operation started three decades ago, the Inter-American judges have been annoyed with the shortage of voluntarism legitimacy among States Parties, and thus, forced to seek other value-centered sources outside Latin America. However, through its steady work to combat serious historical problems in this region, domestic judges have been effectively cultivated to reconstruct democratic values in tandem with the international guardian. Albeit the practice remaining at the embryotic stage, the author optimistically believes that, for a true balance between individual and collective interests, it is the high time for the Inter-American Court to demonstrate its whole-souled trust to regional democratic colleagues equipped with the capacity to generate dependable constitutional reasoning.

\section{Bibliographic references}

Acosta López, J. I. (2016). The Inter-American Human Rights System and the Colombian Peace: Redefining the Fight Against Impunity. American Journal of International Law, 110 (2), 178-182.

Barker, R, S. (2016). Inverting human rights: The Inter-American Court versus Costa Rica. University of Miami Inter-American Law Review, 47 (4), 1-19.

Benavides Hernández, V. and Carvajal Pérez, M. (2016). El Caso Artavia Murillo vs. Costa Rica: control de convencionalidad en el proceso de cumplimiento de obligaciones internacionales. Revista IIDH/Instituto Interamericano de Derechos Humanos, 64, 347372.

Bessson, S. (2009). The authority of international law: lifting the state veil. Sydney Law Review, $31(2), 343-380$.

- (2016). State consent and disagreement in international law-making: dissolving the paradox. Leiden Journal of International Law, 29 (2), 289-316.

Burgorgue-Larsen, L. (2014). La Corte Interamericana de Derechos Humanos como tribunal constitucional. In A. von Bogdandy, H. Fix-Fierro, and M. Morales Antoniazzi, M. (eds.). Ius constitutonale commune en América Latina: rasgos, potencialidades y desafios (pp. 421-457). Universidad Nacional Autónoma de México: México.

Çali, B. (2015). The Authority of International Law: Obedience, Respect, and Rebuttal. Oxford: Oxford University Press.

Cançado Trindade, A. A. (2010). International Law for Humankind: Towards a New Jus Gentium. Leiden: Martinus Nijhoff.

Christiano, T. (2010). Democratic legitimacy and international institutions. In S. Besson and J. Tasioulas (eds.). The Philosophy of International Law (pp. 119-137). Oxford: Oxford University Press.

Contesse, J. (2016). Contestation and Deference in the Inter-American Human Rights System. Law and Contemporary Problems, 79 (2), 123-145.

- (2017). The final word? Constitutional dialogue and the Inter-American Court of Human Rights. International Journal of Constitutional Law, 15 (2), 414-435.

Dulitzky, A. E. (2015). An Inter-American Constitutional Court? The invention of conventionality control by the Inter-American Court of Human Rights. Texas International Law Journal, 50 (1), 45-93.

García-Sayán, D. and Giraldo Muñoz, M. (2016). Reflexiones sobre los procesos de justicia transicional. EAFIT Journal of International Law, 7 (2), 96-143. 
Gerards, J. (2017). The European Court of Human Rights. In A. Jakab, A. Dyevre, and G. Itzcovich (eds.). Comparative Constitutional Reasoning (pp. 237-276). Cambridge: Cambridge University Press (2017).

González-Domínguez, P. (2017). La doctrina del control de convencionalidad a la luz del principio de subsidiariedad. Estudios Constitucionales, 15 (1), 55-98.

Hancco Suyo, G. (2017). Cuando un tribunal interno cuestiona el cumplimiento de una sentencia del tribunal supranacional. Actualidad Constitucional, 114, 234-246.

Hennebel, L. (2011). The Inter-American Court of Human Rights: the ambassador of universalism. Quebec Journal of International Law, (Special Edition), 57-97.

Iovane, M. (2016). The Italian Constitutional Court Judgment No. 238 and the myth of the "constitutionalization" of international law. Journal of International Criminal Justice, 14 (3), 595-605.

Jakab, A., Dyevre, A. and Itzcovich, G. (eds.) (2017). Comparative Constitutional Reasoning. Cambridge: Cambridge University Press.

Lister, M. (2010). The legitimating role of consent in international law. Chicago Journal of International Law, 11(2), 663-691.

Lixinski, L. (2017). The consensus method of interpretation by the Inter-American Court of Human Rights. Canadian Journal of Comparative and Contemporary Law, 3 (1), 65-95.

McGotdrick, D. (2017). Affording States a Margin of Appreciation: Comparing the European Court of Human Rights and the Inter-American Court of Human Rights. In C. M. Buckley, A. Donald, P. Leach (eds.), Towards Convergence in International Human Rights Law: Approaches of Regional and International Systems (pp. 325-365). Leiden/ Boston: Brill.

Negishi, Y. (2016). The subsidiarity principle's role in allocating competences between human rights courts and states parties: the hybrid model of centralized and diffused conventionality control of domestic law. In A. von Bogdandy, F. Piovesan e M. Morales Antoniazzi (eds.). Ius Constitutionale Commune na América Latina, Volume III (pp. 125-160). Curitiba: Juruá Editora.

- (2017a). The pro homine principle's role in regulating the relationship between conventionality control and constitutionality control. European Journal of International Law, 28 (2), 457-481.

- (2017b). Opinio juris as (the ultimate) international secondary rule of recognition: reconciling state consent and public conscience. SSRN European Society of International Law Conference Paper No. 04/2016, 1-25.

- (2017c). Conventionality control of domestic "abuse of power": maintaining human rights and democracy. Italian Yearbook of International Law, 26, 243-264.

Neuman, G. L. (2008). Import, export and regional consent in the Inter-American Court of Human Rights. European Journal of International Law, 19 (1), 101-123.

- (2013). Subsidiarity. In D. Shelton (ed.). The Oxford Handbook of International Human Rights Law (pp. 360-378). Oxford: Oxford University Press.

Palombino, F. M. (2015). Compliance with international judgments: between supremacy of international Law and national fundamental principles. Heidelberg Journal of International Law, 75, 1-27.

Pascual Vives, F. (2014). Consenso e interpretación evolutiva de los tratados regionales de derechos humanos. Revista Española de Derecho Internacional, 66, 113-153.

Pavoni, R. (2015). Simoncioni v. Germany. American Journal of International Law, 109 (2), 400-406. 
Pérez, A. (2017). Una mirada desde América Latina sobre el margen de apreciación estatal en el Tribunal Europeo de Derechos Humanos: ¿génesis de una permanente tensión entre democracia y derechos? Revista Jurídica de la Universidad de Palermo, 15 (1), 79-98.

Potter, P. B. (1925). Relative authority of international law and national law in the United States. American Journal of International Law, 19 (2), 315-326.

Roughan, N. (2013). Authorities: Conflict, Cooperation, and Transnational Legal Theory. Oxford: Oxford University Press.

- (2016). Mind the gaps: authority and legality in unternational law. European Journal of International Law, 27 (2), 329-351.

Ruiz-Chiriboga, O. (2010). The conventionality control: examples of (un)successful experiences in Latin America. Inter-American and European Human Rights Journal, 3, (1-2), 200219.

Tigroudja, H. (2013). The Inter-American Court of Human Rights and international humanitarian law. In R. Kolb and G. Gaggioli (eds.), Research Handbook of Human Rights and Humanitarian Law (pp. 466-479). Cheltenham/Northampton: Edward Elgar.

Tsereteli, N. (2016). Emerging doctrine of deference of the Inter-American Court of Human Rights? International Journal of Human Rights, 20 (8), 1097-1112.

Villagrán Sandoval, C. A. and Carvalho Veçoso, F. F. (2016). A Human Rights' Tale of Competing Narratives. Revista Direito e Práxis, 8 (2), 1603-1651.

Von Bogdandy, A., Ferrer Mac-Gregor, F., Morales Antoniazzi, M., Piovesan, F., and Soley, X. (eds.) (2017). Transformative Constitutionalism in Latin America: The Emergence of a New Ius Commune. Oxford, UK: Oxford University Press.

Werner, W. G. (2016). State consent as foundational myth. In C. Brölmann and Y. Radi (eds.). Research Handbook on the Theory and Practice of International Law-Making (pp.13-31). Cheltenham: Edward Elgar.

\section{International Cases}

IACtHR. Artavia Murillo et al. ("In vitro fertilization") v. Costa Rica. Preliminary Objections, Merits, Reparations and Costs. Series C No. 257. Judgment of November 28, 2012.

- Artavia Murillo et al. ("In vitro fertilization") v. Costa Rica. Monitoring Compliance with Judgments. Order of 26 February 2016.

- Atala Riffo and Daughters v. Chile. Series C No. 239. Judgment of 24 February 2012.

- Baena-Ricardo et al. v. Panama. Series C No. 104. Judgment of 28 November 2003.

- Fontevecchia and D'Amico v. Argentina. Merits. Reparations and Costs. Series C No. 238. Judgment of 29 November 2011.

- Fontevecchia and D'Amico v. Argentina. Monitoring Compliance with Judgment. Order of 18 October 2017.

- Gelman v. Uruguay. Merits and Reparations. Series C No. 221. Judgment of 24 February 2011.

- Gelman v. Uruguay. Monitoring Compliance with Judgment. Order of 20 March 2013.

- Gómez Murillo and otherss v. Costa Rica. Series C No. 326. Judgment of 29 November 2016.

- The Dismissed Congressional Employees (Aguado-Alfaro et al.) v. Peru. Series C No. 158. Preliminary Objections, Merits, Reparations and Costs. Judgment of 24 November 2006. 
- The Massacres of El Mozote and nearby places v. El Salvador. Merits, Reparations and Costs. Series C No. 252. Judgment of 25 October 2012.

- The Massacres of El Mozote and the surrounding areas v. El Salvador. Monitoring Compliance with Judgment. Order of 31 August 2017.

- The Right to Information on Consular Assistance in the Framework of the Guarantees of Due Process of Law. Series A No. 16. Advisory Opinion OC-16/99 of 1 October 1999.

- The Santo Domingo Massacre v. Colombia. Series No. 259. Preliminary Objections, Merits and Reparations. Judgment of 30 November 2012.

\section{Domestic Cases}

Argentina, Corte Suprema de Justicia de la Nación. CSJ 368/1998 (34-M)/CS1. Ministerio de Relaciones Exteriores y Culto s/ informe sentencia dictada en el caso Fontevecchia y D’Amico vs. Argentina por la Corte Interamericana de Derechos Humanos. Sentencia de 14 febrero 2017.

Costa Rica, Sala Constitucional de la Corte Suprema. Ex. 15-013929-0007. Sentencia No 01692/ 2016 de 3 febrero 2016.

El Salvador, Sala de lo Constitucional de la Corte Suprema de Justicia. Inconstitucionalidad 44-2013/145-2013. Sentencia de 13 julio 2016.

Italy, Corte costituzionale Italiana. Sentenzia 238 del 22 ottobre 2014.

Uruguay, Suprema Corte de Justicia. M. L., J. F. F., O.: Denuncia-Excepcion de inconstitucionalidad arts 1, 2 y 3 de la ley 18831. Sentencia No 20/2013 de 22 febrero 2013. 